\title{
Impact of Inflation Targeting Policy Framework of Countries between the Period of 2009-2019
}

\author{
Ananda Rathnayake \\ University of Sri Jayewardenepura, Sri Lanka
}

\begin{abstract}
Today, many countries in the world tend to choose Inflation Targeting Monetary Policy Framework, in which context it has become a matter of debate whether inflation or economic growth is driven by monetary expansions. The common acceptance is that inflation is created by the continuous rise in the money supply which is strongly proved through the economic theories forwarded by Karl Marx, Irvin Fisher and Friedman. The main aim of the study is to examine the relationship between money supply and economic growth under a broad phenomenon by utilizing the countries with inflation targeting policies in action. The time-series data have been collected from different countries that exercise inflation targeting from 2009 to 2019 and the sample included 39 countries from all over the globe, both from developed and developing categories. The utilized Autoregressive Distribution Lag (ARDL) model forwarded the results suggesting that there is a significant negative relationship between the economic growth and money supply in the long run while no relationship has been observed in the short run.
\end{abstract}

Keywords: Economic growth, Inflation targeting, Money supply, ARDL model

\section{Introduction}

In the seminal paper of (Kausar et al., 2020), it is stated that each and every nation aims at attaining sustainable economic development and benefits through the high economic growth rate. The Real Gross Domestic Production (GDP) exhibits a good measure to the economic growth, where many countries have and are still attempting to streamline the growth of the Real GDP in their specific contexts as they believe it will uplift the country to a better economic 
condition. Real GDP is determined by dynamic variables including the money supply but not only limiting to that. However, it can be accepted that every economy is influenced through the pivotal role of the money supply (Kausar et al., 2020).

The monetary policies are implemented to affect the national output through influencing the interest rate, the direction of credits, supply of money, etc. When dating back in history, monetary policy, and effective instruments to regulate the money market came into the plot in 1987. However, there are divergent views about the capability of the money supply in influencing the gross national income. Mohammed Ershad \& Mahfuzul (2017) and Ogunmuyiwa \& Ekone (2010) have observed a positive linkage between the two variables, money supply and economic growth rate of the economies while earlier studies of (Moosa, 1982), (Odedokun, 1996), (Levine, 1997) and (Ghosh \& Philips, 1998) have argued emphasizing that there is a significant negative nexus between money supply and growth rates. According to Keynesian views, money supply has had a positive but a very insignificant impact on the growth rate of the economy (Twinoburyo \& Odhiambo, 2017). In seminal papers, (Kamaan, 2014), (Chipote \& Palesa, 2014), Chipote \& Palesa (2014) and Inam \& Ime (2017) have investigated that the influence from the money supply expansion on the growth of economy is very insignificant. Among previous works that advocated that there is a significant strong influence from monetary expansion in boosting the economic growth, Nouri \& Samimi (2011) and Onyeiwu (2012) are important. Also the earlier studies including Qayyum (2006) and Zapodeanu \& Cociuba (2010) etc. have examined the nexus that exists between money supply and growth rates but no evidence can be drawn from the academic history which considered the nexus that exists between these two variables in the countries where the Inflation targeting framework is in action.

The attention in analyzing the money supply-growth nexus has increased due to the divergent views on this relationship (Jawaid et al., 2011). Therefore, the dissimilar perspectives in relation to the linkage between money supply and growth levels have laid the foundation to do a further analysis of the short and long run relationship between the two factors to have a clear idea. On the other hand, Patrick Kanayo \& Ifeoma (2015) has declared that money printing is conducted to reach the economic growth by many countries. However, printing money was always a debatable phenomenon whether it is effective in stimulating the growth of the economies. Economists believed that a high volume of money released to the community has the possibility in generating inflation and hyper-inflationary situations. This obviously brings negative 
consequences making the low income earning households to suffer a lot (Wellington Garikai, 2015). With these dissimilar viewpoints on the money supply-growth nexus of the economies, the current study provides an extensive contribution to have a clarified analysis on this subject matter with a novel consideration of the Inflation targeting framework. The study is important in different facets. Firstly, the study has given a strong focus to the Inflation targeting policy framework that is adopted by different nations to achieve economic growth. The uniqueness of this study is that it broadly examines, both the short and long run nexus between money supply and economic growth, considering the majority of countries who are exercising Inflation targeting policies in their economies. The contribution of the study to the literature is very significant as it provides a very comprehensive analysis on both the short and long run relationship between the money supply and economic growth by occupying the PARDL model. The practical importance of the study is highlighted from its contribution to bring more realistic policy insights for the countries in order to stimulate the economic growth. Moreover, through the study, a great assistance is given to the policy makers of the countries to make decisions on employing the expansionary or contractionary monetary policies, as the study has contributed with a clear discussion about the short and long run impact over the growth rates. Also, the study assists the policy makers to employ expansionary or contractionary monetary policies with clear pictures about its short and long run impact over the growth of the economy.

\section{Literature Review}

\section{Theoretical review}

The Inflation targeting concept was started a decade ago in New Zealand and Chile as a means of achieving a low and stable level of inflationary pressures (Bernanke \& Mishkin, 1997). The Inflation targeting came into the plot due to the harmful effects of the inflation in the1980s (Vredin, 2015). By the end of the 1980s the cross-country analyses and large surveys carried out showed the negative effects of high and variable inflation on the macroeconomic stability, economic growth, and income distribution (Guy et al., 1998). Hence, the controlling of inflation through setting a particular target and adjusting the monetary policy tools to reach that target is simply known as Inflation targeting. However, Inflation targeting acts as an important aspect when accelerating the money supply to increase the output level of the economy. There are two prerequisites for adopting the Inflation targeting. They can be stated as the independence of the monetary policy and no commitment to a certain level of 
exchange rate. When a country is met with the above mentioned prerequisites, it can conduct the monetary policy under the Inflation targeting framework. There are seven countries that have succeeded in meeting the conditions specified above and they have been able to adopt the Inflation targeting framework. Their key aim via the Inflation targeting framework is achieving a lower inflation rate which is less than 10 percent. With that, they try to maintain a considerable flexibility in exchange rates and the independence of the Central Bank conditions. Hence, this is a novel concept to most of the emerging economies but there is a growing trend in the number of countries that adopt Inflation targeting policies (Hammond, 2011).

Since the past, the as of now developed theories around the money supplygrowth nexus have basically been contended by distinctive parties and different opinions have been produced in connection to this relationship that exists between the money supply and economic growth (Hameed \& Ume, 2011). Monetary policy can be identified as one of the significant policies that conduct a vital role in boosting up the economic growth of many countries. However, there has been a long debate since the past to figure out whether there is an actual impact from money supply adjustments towards the growth of the real Gross Domestic Product (GDP) of the countries.

There are a few theoretical approaches that have laid the foundation for analyzing the money supply-growth nexus including the Quantity Theory of Money (QTM), Cambridge Cash Balance Theory and Keynesian Theory(Chaitip et al., 2015). An obvious relationship between the money supply and output level exists as per the Quantity Theory of Money, and as per the exchange equation of $(\mathrm{MV}=\mathrm{PY})^{1}$. Fisher has assumed that the output is constant and believed that the economy is always in the full employment level where no effect can be observed from the increase or decrease of money supply on the output levels. As per the monetarist views, they believe that monetary policy affects prices, that means inflation, and the real GDP of the countries while affecting unemployment too (Chaitip et al., 2015). The pioneering economist to introduce the monetarist theory was Friedman. The monetarist theory has emphasized the money supply as an important macroeconomic determinant of the growth of any nation. According to the monetarists' views, when the increase of the money supply takes place, people tend to increase the demand levels, and factories also increase their production levels. In that case,

\footnotetext{
${ }^{1}$ Fisher's (1911) exchange equation (MV=PY) is recognized as one of the foremost popular classical numerical equations. Through the Fisher's equation the casual linkage between the money supply and price levels has been well discussed.
} 
new job opportunities emerged addressing unemployment issues in that particular nation (Ahuja, 2015) . The argument that highlights the long run impact of the money supply on the inflation rates has been stressed by the adherents of the monetarist theory while they further emphasized the short term effects on employment and output level. (Denbel et al., 2016). As per their considerations, they highly believed that amount of the money supply is the most important element relative to the other factors as it has a strong potential in affecting economic growth. They also advocate that the monetary policies that exercise adjusting the money supply in the economy are high in terms of the effectiveness and being fruitful than the fiscal policies that were composed with only debts, taxes and government expenditure. According to them, the Central Banks of different nations play a vital role in determining the money supply and they are considered more influential than the governments of those countries. Hence, as the monetarists argue, when the money supply of a country increases, the performance of the economy will also rise and decrease when the money supply declines (Ogunmuyiwa \& Ekone, 2010). The Cambridge Cash Balance Theory put forwarded by neo-classical economists from the Cambridge school have highlighted that the money supply can affect the prices and output levels of the countries in the short run but can only affect the price levels in the long run. Through the Equation of Cambridge ${ }^{2}$, they have pointed out that the money supply is proportionately linked with the nominal per capita income or output level (Chaitip et al., 2015).

Keynesians also forwarded arguments elaborating the positive linkage between the two variables, money supply and growth of the countries. They believed that the money supply changes will have the potential in changing the real output level and the price level of the countries. Hence, Keynes in 1936, created the liquidity preference theory to stress that the liquidity of the economy is a good dimension for the economic growth. The theory states that the money demand arises due to the motive of the people to remain liquid. As per John Maynard Keynes, the communities keep money stocks for their main motives including transaction, precautionary and speculative and the no presence of the purposes will reduce the growth of the country (Ogunmuyiwa \& Ekone, 2010).

Inflation can be characterized as the persistent increment within the general price level or the prices of products (Shuaibu \& Isa, 2011). Simply, this can be identified as too much money chasing fewer amount of goods. Inflation will create a decline in the purchasing power of money. The research studies that

\footnotetext{
${ }^{2}$ Neo classical economists have reformed the Exchange Equation and created the Equation of Cambridge(Chaitip et al., 2015).
} 
have been conducted centering on the relationship between the inflation rate and growth levels have an incredible history where they came to begin with through the classical economic theories (Krogh, 1967, and Aydın et al., 2016,). The vital role of the inflation rate in boosting the growth rate of the countries is a subject that remains a critical debate (Temple, 2000). The Central Bank of each nation aims to maintain a lower level of inflation through the adjustments to the monetary policy tools while reaching high economic growth for the country. There are plenty of pieces of evidence to prove how the very high level of inflation has brought drastic negative effects on the economic growth of the countries (Temple, 2000). As per the classical theories, the inflation-growth nexus is implicit and negative. As per Adam Smith, the classical theory had assumed that the savings are the most important determinants of economic growth while also bringing their assumption that no direct relationship can be observed between inflation and its tax effect on the output level of the country (Gokal \& Hanif, 2004).

Another facet of the classical theory, the Quantity theory of money has reflected that money has no potential to affect the real variables in the long run, but it influences the determination of the price levels of the country. Despite the unclear and implicit effect of the inflation rate on the economic growth, inflation brings negative consequences on the economic growth of the countries (Boyd \& Champ, 2006). The same study has conducted a theoretical insight that inflation has the potential in reducing the real return on assets. More specifically, it discourages investments in the country while discouraging economic growth as a result. Through inflation, savings will be discouraged, and borrowings will be encouraged to make hikes in the nominal interest rates. The conventional views on inflation emphasized the importance of maintaining it at moderate and stable levels to improve the economic activities in a country. As per the monetarists, which were led by Milton Friedman, inflation can be identified as a monetary phenomenon that exists everywhere. They believed that the root cause of inflation is mainly generated through the increase of the money supply or through implementing the expansionary monetary policy. Simply this emphasized that through the increases in money supply, a rapid increase in inflation can be observed. As per the monetarist model, inflation is regarded as a function of the money supply. It can be observed that there is a lack of consensus among the views of different scholars concerning the linkage that exists between the inflation rate and the level of money supply. Bashir et al. (2011) identified that there is a significant positive relationship between the 
money supply and inflation while Dlamini and Armstrong (2001) have reflected that there is an insignificant impact over the inflation from the money supply.

West African Monetary Agency (2009) as cited in Evans Ovamba (2014) has indicated that the linkage between these two variables, inflation rates and the money supply is determined by the peculiar instances of the countries. They have shown how the inflation appeared a positive relationship with money supply within the nations counting Guinea-Bissau, Mali, Ghana, Benin, Cape Verde and Liberia whereas a negative relationship between the two factors concerning the nations counting Burkina Faso, Cote d'lvoire, Niger. When it is observed the countries that have shown a positive linkage between the inflation and the money supply, Gambia and Guinea have shown an above 0.7 statistical relationship which can be declared as a strong positive relationship (Evans Ovamba, 2014). As per the findings of Akinbobola (2012) it was confirmed that the money supply and exchange rates have significant inverse influence over the inflationary pressure of the country in the long run. On the other hand, real output growth and foreign price changes have a coordinated effect on inflation. The reason for this is the glitches of the supply chains of the goods which are both from the local and foreign supply stores. Qayyum (2006) attempted to investigate the linkage between inflation and the money supply and the results indicated that there is a positive association between these two variables.

\section{Empirical review}

As per Mohammed Ershad \& Mahfuzul (2017), the empirical analysis in terms of the linkages in between the money supply and the growth of Bangladesh' economy, was done using the Vector Error Correlation Model (VECM). Accordingly, the study showed that there is a significant role for money supply in boosting the growth rate of the country via reflecting a positive nexus between the variables. Going beyond that, Chaitip et al. (2015) have investigated the same fact that the relationship between these two variables are positive and the investigation is done using the Autoregressive Distribution Lag (ARDL) model. When considering the content of the research, they have primarily attempted in figuring out the influence of money supply on economic growth for Authorized Economic Operators (AEO) open region by taking the period from 1995 to 2013. Ogunmuyiwa \& Ekone (2010) examined the correlation between the money supply and economic growth for the Nigerian context and they have employed the Error Correction Model throughout 19202006. As per the final results gained, they have attempted to depict that money supply is positively related to the growth rate. Similar significant and a positive 
nexus between the two variable has been presented by Shuaibu \& Isa (2011). They have utilized the time period from 1975-2008 and have employed the ARDL model. The same ARDL model was employed by Chude \& Chude (2016) to analyze how the broad money supply influences the growth rate of Nigeria from 1987-2010.

Another important research which was conducted by Suleman et al., (2009) has utilized the Johanson cointegration model to build up arguments about the effects of the money supply adjustments over the economic growth rates. Also, they have conducted a comprehensive study that was involved in finding the nexus between the broad money supply, the state expenditure, the level of output and the inflation rate for Pakistan by considering the period from 19772007 and revealed that positive nexus exists between the two variables. Furthermore, Hameed \& Ume (2011) have examined the effects of the monetary policies on the production levels of Pakistan and they have reflected that money supply exhibits a positive and a significant impact over the GDP growth of Pakistan. Moreover, Ihsan \& Anjum (2013) have employed the Engle-Granger and ARIMA model for the examination of the positive relationship between the money supply and gross domestic product for Pakistan. The same model was used by Zapodeanu \& Cociuba (2010) to investigate the linkage between the GDP and money supply and they found the relationship is significant and positive. To test the cointegration between the money supply and output in Singapore, Maitra (2011) has used the cointegration model and has identified how the money supply and output are cointegrated during the period from 19711972. Using the multivariate econometrics variables the study of Mohamed Aslam (2016), examined the effect of money supply on growth of Sri Lanka for the period from 1959-2013. However, the study concluded that there is a positive nexus between the economic growth rate and money supply.

Apart from the studies that have reflected the positive relationship between the two factors, a few other critical studies have been conducted to examine the nexus between the factors and have found a negative relationship. Liang \& Teng (2006) employing the Fully Modified Ordinary Least Squared (FMOLS), investigated Ghana's financial performance and growth rates. The revolutionary finding was that the country's money supply constrained the economic growth. Gatawa et al.,(2017) have figured out that money supply, economic growth, and inflation for Nigeria from 1973 to 2013 have depicted that the broad money supply and interest rates are negatively related to the economic growth. To carry out the investigation they have used the VECM model. Moreover, Ihsan \& Anjum (2013) have distinguished the impacts from the money supply on the 
growth during the time period from 2000-2011 of Pakistan and they have used different economic dimensions to reach their conclusion that a significant negative relationship exists between the money supply and growth rates. Lastly, Kizito (2013) has studied the nexus between the money market and economic growth and has identified that there is a negative relationship between economic growth and money supply. For this study, they have employed the VECM model. Inam \& Ime (2017) have identified the effects of the monetary policy on Nigeria's economic growth by applying the Ordinary Least Squares (OLS) method and Granger Causality Test. To do the effective data analysis the study has used the macroeconomic data of Nigeria from 1970 to 2012. The study has concluded that a negative nexus exists between the growth and the money supply. Njimanted et al., (2016) have used the Vector Auto-regression (VAR) method to analyze the influence of the monetary policy tools on the economic growth of the Central African Economic and Monetary Community (CEMAC). To indicate the monetary policy which was the independent variable of the study they have utilized the money supply, interest rates, and inflation rates. The study has highlighted that the money supply negatively affects growth levels of the CEMAC community in diverse areas.

However, when it comes to the study done by Kamaan (2014) by conducting an effective statistical analysis, it has reflected that there is no significant impact from the monetary policy on the economic growth of Kenya. Chipote \& Palesa, (2014) have used the Error Correction Model and Johanson Cointegration model to identify the influence of the money supply adjustments on the growth in South Africa for the period from 2000 to 2010. The study found that the money supply composed with an insignificant impact on the economic growth in South Africa.

There are a large number of studies that have been conducted to identify the linkage between the growth and money supply. The studies have forwarded many divergent views on the money supply-growth nexus. Subsequently, the study is theoretically noteworthy because it helps to distinguish the precise nature of the short and long run relationship between the money supply and economic growth. Also, the research gap arises as all the previous studies have not considered the Inflation targeting framework when analyzing the money supply-growth nexus. Hence, the empirical significance of the study is highlighted as the Inflation targeting framework is largely concerned through the study enhancing the generalizability of the findings.

\section{Methodology}


The research work adopted the quantitative approach which can be identified as the ex-post facto approach. The time series data have been collected from different countries who exercise Inflation targeting from 2009 to 2019 using the World Development Indicators, developed by World Bank. The secondary data were collected from 39 countries which were listed in International Monetary Fund (IMF) staff calculations including UK, Sweden, Israel, Chile, South Africa, Peru, Indonesia, Serbia, Paraguay, USA, Uganda, Japan, New Zealand, Czech Republic, India, Russia, Colombia, Brazil, Canada, Kazakhstan, Russia, Moldova, Poland, Mexico, Thailand, Australia, Hungary, Iceland, Korea, Republic of, Norway, Philippines, Guatemala, Romania, , Republic of, Turkey, Armenia, Ghana, Uruguay, Albania, Georgia, and Dominican Republic where Inflation targeting policies have been in place. These countries were selected for the sample because they were the first to adopt an Inflation-Targeting Monetary Policy Framework.

The production function is represented by the functional form given in Equation (1).

$Y=f(K, L)$

The above function includes $\mathrm{Y}$ representing the output in real terms, $\mathrm{K}$ representing the total capital units while $\mathrm{L}$ represents the total labor units.

The foundation of the modern growth theory was introduced in the 1950s. The efforts of Tinbergen (1959) to explain the production growth in Germany, the United Kingdom and France with the use of the Cobb-Douglas production function while considering capital and labor as explanatory variables was elaborated above. However, empirical works have made great attempts in developing an endogenous growth model with the use of Barro's findings. Barro, who is a pioneering economist in new empirical growth studies has investigated factors like country's inflation rate, trade openness, human capital, and interest rates as the major determinants of growth. Burnside \& Dollar (1997) have declared that the effective and strong fiscal, monetary and trade policies have the potential in boosting the economic growth of developing countries. The statistical study of the World Bank also concluded that human capital, educational level, and skill level of the people have a large impact on increasing the economic growth (The World Bank Group, 1993). William Easterly has investigated that there is a strong relationship between trade openness and economic growth. The findings further elaborated that there are three benefits of trade openness on economic growth, including promotion of investment level, promotion of convergence of rich and poor nations and improvement of the allocation of investment (Barro, 1990). 
Based on the above literature findings, the present study has gathered data in relation to the variable of Real GDP growth rate, which is the indicator of economic growth of countries, the dependent variable of the study, (M2) money supply which is the indicator of monetary policy and the independent variable of the study, controlling variables including labor force participation rate, exchange rate, trade openness, real interest rate of the countries for the period from 2009-2019. Moreover, the inflation rate is the moderating variable for the money supply- growth nexus.

Thus, the present study extended the equation as follows:

$Y=f(M S, L F P, E R, T O, R I)$

Y represents economic growth, MS denotes money supply, LFP represents the Labor Force Participation, ER denotes Exchange rates, TO denotes Trade Openness and RI denotes Real Interest Rate of the countries.

In order to continue with the analysis, the present study has employed the same Autoregressive Lag model to do the estimation of equation (2). This model can be justified as very useful in testing the long and short run effects of the variables. The vast number of "X" variable growth nexus analyzing studies have employed ARDL, as this method is more suitable regardless of whether the regressors exhibit $\mathrm{I}(0), \mathrm{I}(1)$ or a mixture. The studies have used the ARDL model to test the effects of the different variables including energy and growth (Menegaki, 2019), government debt and growth levels of the countries (Asteriou et al., 2021), prices of shares in the stock market and inflation (Akmal, 2007), inflation and exchange rate effects on stock market returns (Kwofie \& Ansah, 2018). A similar method is used by the present study to analyze long and short run effects from money supply on economic growth.

The endogeneity problem has been eliminated through the ARDL approach and the nexus between growth and money supply has been analyzed in a dynamic specification with lag values of the dependent variables and the independent variables (Murthy \& Okunade, 2016). The following specified equation is in relation to the utilized model for the study.

$$
\begin{aligned}
& \Delta \ln Y t=a+\sum_{j=1}^{n=1} \beta_{j} \Delta \ln Y_{t-j}+\sum_{j=0}^{n=2} \gamma_{j} \Delta \ln M S_{t-j}+\sum_{j=0}^{n=3} \delta_{j} \Delta X_{t}+ \\
& \theta_{1} \ln Y_{t-1}+\theta_{2} \ln M S_{t-1}+\theta_{3} \ln X_{t}+\varepsilon_{t}
\end{aligned}
$$

$\ln Y_{t}$ denotes natural $\log$ values of the Real GDP growth rate in the year $\mathrm{t}, \ln Y_{t-j}$ represents natural log values of the Real GDP growth rate in the year t-j, $\ln M S_{t-j}$ represents natural log values of money supply in the year $\mathrm{t}-\mathrm{j}$. Other independent 
variables are denoted by $\mathrm{X}_{\mathrm{t} .}$. They include Labor Force Participation (Barro, 1990), Real Interest Rate(Barro, 1990), Exchange Rate (Akinbobola, 2012) and Trade Openness (Barro, 1990). $\beta_{j}, \gamma_{j}, \delta_{j}$ were used as the parameters of short run while long run parameters are stated through $\theta_{1}, \theta_{2}$ and $\theta_{3}$. Error term is $\varepsilon_{t}$.

Following null hypotheses were stated to be tested through the study which were to identify whether the adjustments to money supply or the money stock in the economy has any effects on economic growth under the Inflation targeting framework.

Hypothesis 1: Long run impacts from money supply on growth does not exit Hypothesis 2: Short run impacts from money supply on growth does not exit

As the first stage, all data were tested for the stationarity utilizing the panel unit root test. There are many types of panel unit root tests and the study has used Im, Pesaran and Shin W-stat, ADF-Fisher, and PP - Fisher Chi-square. The second stage involved with examining the linkage between the above variables giving priority to the relationship between the money supply and real GDP growth rate considering the panel ARDL approach both in the short run as well as in the long run (Pesaran et al., 1999).

The basic assumption that was made when analyzing the relationship among the variables utilizing the ARDL approach is that the variables are stationery at the first level. The analysis might not be feasible in being carryied out further if the variables were stationery at the second level. Therefore, as the first step of the study, the data variables were analyzed to ensure the pre criteria of stationarity at the first level. As mentioned earlier the study utilized the Im Pesaran and Shin W-Stat, PP-Fisher Chi-Square, ADF-Fisher criteria, for the panel unit root tests. The two additional hypotheses in relation to the unit root criteria are stated as follows.

H0: The variables are not stationery at first level

$\mathrm{H1}$ : The variables are stationery at first level

The results can be interpreted as follows.

Table 1: Summary of unit root tests conducted

\begin{tabular}{lccc}
\hline Variable & $\begin{array}{c}\text { Im, Pesaran and Shin } \\
\text { W-stat }\end{array}$ & $\begin{array}{c}\text { ADF- Fisher Chi- } \\
\text { square }\end{array}$ & $\begin{array}{c}\text { PP-Fisher Chi- } \\
\text { square }\end{array}$ \\
\hline LN_RDGP & 0.0000 & 0.0000 & 0.0000 \\
LN_MS & 0.0000 & 0.0000 & 0.0000 \\
LN_LFPR & 0.0001 & 0.0000 & 0.0000 \\
LN_ER & 0.0000 & 0.0000 & 0.0000
\end{tabular}




\begin{tabular}{llll} 
LN_TO & 0.0000 & 0.0000 & 0.0000 \\
LN_RII & 0.0003 & 0.0000 & 0.0000 \\
\hline
\end{tabular}

With the significance level of $95 \%$, as the Im, Pesaran and Shin W-stat, ADFFisher Chi-square and the PP-Fisher Chi-square fall under 0.05, the rejection of the null hypothesis can be done stating that the variables are stationery at the first level, or no unit root issues can be detected.

\section{Analysis and Discussion}

The focus of the study has been directed towards the analysis of the short-run as well as the long-run relationship of the variables, mainly with the prioritized concentration on the nexus between Broad Money Supply which is the indicator of the monetary adjustment of countries and the Growth rate of Real Gross Domestic Product, which is the indicator of economic growth.

Table 2 and Table 4 elaborate the long run and short run co-integration estimates of the Equation (3) respectively.

Table 2: Long Run ARDL Cointegration Model

\begin{tabular}{ll}
\hline Model, selection method and variables & Method and values \\
\hline Selected model & ARDL $(1,7)$ \\
Model selection method & Hannan-Quinn criterion (HQ) \\
Included observation & 395 \\
Bound Test F Statistics for small samples & $94.19^{* *}$ \\
Dependent variable & \\
LN_MS & $-0.0044^{* *}$ \\
Independent variables & \\
LN_ER & $0.0001^{* *}$ \\
LN_RI & $0.0316^{* *}$ \\
LN_LFP & $-0.0534^{* *}$ \\
LN_TO & $0.0657^{* *}$ \\
@TREND & $0.394^{* *}$ \\
\hline
\end{tabular}

Notes

a. The model is estimated with constant and trend with one lag of Real GDP and seven lags for Money Supply (MS) (1,7) based on the Hannan-Quinn criterion (HQ)

b. *,** and ${ }^{* * *}$ represent the significant levels of $10 \%, 5 \% .1 \%$ respectively

Source: Data Analysis by the author

An exceedingly noteworthy negative relationship between the money supply and growth rates is displayed within the long run and this has been depicted through the above table. As the p-value coefficient is less than 0.05 , the null 
hypothesis cannot be accepted, and therefore, it can be expressed that there's a noteworthy negative effect from monetary expansion on economic growth within the long run. This is a contradictory finding when compared with the traditional conclusions of Monetarist and Keynesian theories, as both of them have advocated that there is a positive impact from money supply on economic growth. As per Monetarists' arguments, when the country's money supply rises, there is an increase in the economic growth of the countries and a decrease when the money supply declines (Ogunmuyiwa \& Ekone, 2010).

The findings are well aligned with the studies of Liang \& Teng (2006) which had utilized the Modified Ordinary Least Squared and investigated that the money supply-growth nexus is negative, Gatawa et al. (2017) have investigated that money supply and interest rates are negatively linked with the economic growth. Ihsan \& Anjum (2013) depicted a negative relationship between the growth and money supply and Kizito (2013) delineated that there's a negative relationship between the economic growth and money supply.

On the other hand, real interest rate, labour force participation, exchange rate, and trade openness can be stated as the most influential factors of the long-run growth of the countries. Trade openness, exchange rates, and real interest rates showed a positive significant relationship with the long-run economic growth while labour force participation rate depicted a significant and a negative relationship. The summary of the nature and strength of the key determinants of the long-run economic growth has been elaborated through Table 3.

Table 3:Realtionship between the variables and the economic growth in the long

run

\begin{tabular}{lllll}
\hline Variable & $\begin{array}{l}\text { Nature of the relationship } \\
\text { with economic growth }\end{array}$ & $\begin{array}{l}\text { Strength } \\
\text { relationship }\end{array}$ & of \\
\hline MS & Negative & Significant & \\
LFPR & Negative & Significant & \\
ER & Positive & Significant & \\
TO & Positive & Significant & \\
RII & Positive & Significant & \\
\hline
\end{tabular}

Source: Data Analysis by the author

Similarly, the short-run analysis emphasized that the money supply adjustments do not show a relationship with the economic growth in the short run through the insignificant short-run coefficients depicted in Table 4. Therefore, Hypothesis 2 failed to be rejected stating that there is no significant impact from monetary adjustments on economic growth in the short run at a $95 \%$ confidence 
level. As per Gatawa et al. (2017), the key reason for this is the misallocation of resources.

Table 4:ARDL model estimates

\begin{tabular}{ll}
\hline Model, selection method and variables & Method and values \\
\hline Selected model & ARDL $(1,7)$ \\
Model selection method & Hannan-Quinn criterion (HQ) \\
Included observation & 395 \\
Bound Test F Statistics for small samples & $94.19^{* *}$ \\
Endogenous variables & \\
D(LN_MS) & $4417^{* *}$ \\
D(LN_MS(-1)) & $-1.273^{* *}$ \\
D(LN_MS(-2)) & $-0.0005^{* *}$ \\
D(LN_MS(-3)) & $-0.0007^{* *}$ \\
D(LN_MS(-4)) & $-0.0005^{* *}$ \\
D(LN_MS(-5)) & $-0.0011^{* *}$ \\
D(LN_MS(-6)) & $-0.0014^{* *}$ \\
Exogeneous Regressors & \\
LN_ER & $0.0001^{* *}$ \\
LN_RI & $0.0316^{* *}$ \\
LN_LFP & $-0.0534^{* *}$ \\
LN_TO & $0.0657^{* *}$ \\
LN_RI & $0.0316^{* *}$ \\
C & $54.4^{* *}$ \\
CointEq(-1) & $0.0047^{* *}$ \\
\hline
\end{tabular}

Notes

a. The model is estimated with constant and trend with one lag of Real GDP and seven lags for Money Supply (MS) $(1,7)$ based on the Hannan-Quinn criterion (HQ)

b. *,** and ${ }^{* * *}$ represent the significant levels of $10 \%, 5 \% .1 \%$ respectively

Source: Data Analysis by the author

The summarized results can be depicted as follows in relation to the relationship that exists between the economic growth and each of the variable in the short run.

Table 5: Relationship between the variables and the economic growth in the short

\begin{tabular}{lc}
\multicolumn{2}{c}{ run } \\
\hline Variable & Strength of the relationship \\
\hline MS & Insignificant \\
LFPR & Insignificant \\
ER & Insignificant \\
TO & Insignificant
\end{tabular}


Source: Data Analysis by the author

The results emphasized that it could observe a long-run influence from monetary adjustments towards the growth of economies in the countries that exercise Inflation targeting policies in their contexts. In any case, no effect of monetary alterations on the economic growth within the short run can be distinguished in these specific settings with Inflation targeting policies.

The findings are similar to Liang \& Teng (2006) which has investigated a negative linkage between monetary policy adjustments and economic growth in the long run in Ghana. Also, the same findings were identified by Gatawa et al. (2017) where they figured out that money supply and inflation in Nigeria from the period from 1973-2013 negatively related to the economic growth rate. Also, the findings match with the investigation of long-run negative linkage among the growth of the economies and monetary adjustments by Kizito (2013). Going beyond all, the studies are contradictory with Mohamed Aslam (2016) who has identified a long-run positive nexus between the economic growth rate and money supply in the Sri Lankan context. The same relationship, a long-run significant positive linkage between the money supply and economic growth in Nigeria was figured out by Shuaibu \& Isa (2011). In any case, the study has portrayed that within the short and long run there is a negative relationship between the two factors with no solid generalizability by taking Inflation targeting policies into consideration. The findings of this study have uncovered that a critical relationship is absent between money supply and the economic growth within the short run. A large majority of the seminal papers have identified that the relationship between the growth and money supply is very insignificant in the short run. For instance, Fanta (2013) observed that there is no evidence to state a cointegration between the broad money supply and real GDP in the short run and as the reason, they have stated the heavy economic uncertainties that exist. As per Ahuja (2015), achieving the growth in the short run through the adjustments in money supply may be in conflict with the exchange rate instability. Hence, if the countries do not possess a stable exchange rate regime, the expansionary monetary policy will not be supportive enough to reach economic growth in the short run. The global financial crisis (2006-2013) and China-United States trade war (2018-2020) have led to economic uncertainty in the world and there have been sharp fluctuations in foreign exchange rates in the recent past. In that environment, economies have not been able to achieve economic growth in the short run by increasing the 
money supply, even under a technologically advanced Inflation Targeting Monetary Policy Framework.

Another important finding of the study is that in the long run, a negative and a significant nexus exists between the money supply and growth of the economies. Ross (2020) argues that the long run impact of the money supply on the economic growth is very difficult to predict and clearly interpret. History has suggested that there is a heavy tendency for the asset prices including the house prices, stock prices to rise with the increase of the money supply. This is mainly due to the high liquidity pumped into the economy. As per the findings of Inam \& Ime (2017), the countries have failed to attain the desired macroeconomic goals including the streamlined economic growth due to their failures to maintain money stocks at growth friendly levels. With the increase of the money supply, the debt overextension can happen generating the damages to the economic activities in the long run. This is mainly because high debts are not sustainable over a long period of time. The root cause for the credit crisis in 2008 was the overextension of the debt (Mohamed Aslam, 2016). As per the Liquidity view, the money supply and interest rate compose with a negative association. In that case, the expansionary monetary policies have the capability in lowering the interest rates, and increasing the borrowings of the people. However, if the communities do not demand the loans as expected, the expansionary monetary policy will not assist the growth rates (Kaplan, 2017). As per Kurniasih (2019), a positive relationship has been examined between the rate of interest and the money supply. Hence, when the expansionary monetary policy efforts are taken in relation to the selected contexts of the study, it could be identified that the interest rates are increased in the economies making the people motivated to take less loans. As the interest rates are high taking loans becomes expensive. The same theory has been suggested through the Fisher views ${ }^{3}$ where the studies suggest that a positive relationship could be identified in between the money supply and interest rates. Therefore, by being aligned to the above findings, the key reason for less impact over the Real GDP growth is the less motivation to take loans and less investments to scale up the production processes. The inefficiencies in the allocation of the resources has become one of the root causes for the negative relationship between the two variables. However, this can be argued in another facet as well. As per Ross (2020), when interest rates rise due to the money supply expansions, savers get the capability

\footnotetext{
${ }^{3}$ The Fisher effect emphasizes that the nominal interest rate changes in reaction to the changes that take put within the money supply. In any case, the Fisher impact shows up within the long run but may not be present within the short run.
} 
to earn more and they tend to deposit more delaying the present consumption. Hence, even though expansionary monetary policy has been employed, the Aggregate Demand will be lowered ultimately reducing the real output of the economies. In the economic sense, Keynesian view has brought the Liquidity preference theory ${ }^{4}$ arguing that the increase in money tends to lower the interest rates. This simply identified that there is a negative relationship between the interest rates and money supply. This will stimulate the investments and expect economic growth. In that case, it can be identified that the investment expenditure here is not increased as the suggestion of the Keynesian Liquidity Preference Theory.

\section{Concluding Summary}

The primary aim of carrying out the current analysis was to test the influence of the money supply on the growth rates in the countries that have exercised Inflation targeting policies. To reach the stated research objective, broad money supply was taken as the main exogenous variable and the other independent variables including the labor force participation rate, exchange rate, real interest rates, trade openness were considered as controlled variables in the study. The key dependent variable was elaborated through Real GDP growth rate which can be identified as the key measure of the economic growth. As per the estimated model, money supply significantly and negatively impacts the economic growth in the countries in the long run where Inflation targeting policies are implemented. Also, such a relationship among the tested variables, including money supply and growth of the countries could not be observed in the short run. Accordingly, the main conclusion of this study is that increasing the money supply within the Inflation Targeting Monetary Policy Framework does not stimulate economic growth in the short run or long run.

The study has contributed vastly to the academic rigor through the comprehensive analysis conducted by employing the ARDL model about the short and long run impact of money supply over the economic growth rates. This has eased the policy makers' responsibilities in taking necessary action priorities to exercise the monetary policy efforts with the intention to boost up the economic growth. The process is assisted through the evaluation of the nexus between growth rates and the money supply in relation to two time periods, short and long run.

4 Liquidity Preference Theory proposes that speculators ask persistently higher premiums on medium and long-term securities as negated to short-term securities. 
As for recommendations, it can be stated that money printing should not be exercised by the governments as a mechanism to boost up economic growth, as money printing will not be effective in two time periods, short and long run. The short-run zero nexus between the money supply and economic growth rate show that some of the expansionary monetary policymaking procedures seeking increased economic growth rate have been misleading. Moreover, in the long run, the expansionary monetary policy efforts will not generate positive implications on the economic growth.

\section{Declaration of Conflicting Interests}

The author declared no potential conflicts of interest with respect to the research, authorship, and publication of this article.

\section{References}

Ahuja, H. . (2015). Macroeconomics Theory and Policy. S. Chand Publishing. https://books.google.lk/books?id=wDscEAAAQBA

Akinbobola, T. O. (2012). The Dynamics of Money Supply, Exchange Rate and Inflation in Nigeria. Journal of Applied Finance \& Banking, 2(4), 117-141.

Akmal, M. (2007). STOCK RETURNS AND INFLATION: AN ARDL ECONOMETRIC INVESTIGATION UTILIZING PAKISTANI DATA. Pakistan Economic and Social Review, 45(1), 89-105.

Asteriou, D., Pilbeam, K., \& Pratiwi, C. E. (2021). Public debt and economic growth: panel data evidence for Asian countries. Journal of Economics and Finance, 45(2), 270-287. https://doi.org/10.1007/s12197-020-09515-7

Aydın, C., Esen, Ö., \& Bayrak, M. (2016). Inflation and Economic Growth: A Dynamic Panel Threshold Analysis for Turkish Republics in Transition Process. Procedia - Social and Behavioral Sciences, 229, 196-205.

Barro, R. J. (1990). Government Spending in a Simple Model of Endogeneous Growth. Journal of Political Economy, 98(5, Part 2), S103-S125.

Bashir, F., Nawaz, S., Yasin, K., \& Quresh, M. J. (2011). Determinants of inflation in Pakistan: An econometrics analysis using JohansenCo-integration approach. Australian Journal of Business and Management Research, 1(5), 71-82.

Bernanke, B. S., \& Mishkin, F. S. (1997). Inflation Targeting: A New Framework for Monetary Policy? Journal of Economic Perspectives, 11(2), 97-116.

Boyd, J. H., \& Champ, B. A. (2006). Inflation, banking, and economic growth.

Burnside, C., \& Dollar, D. (1997). Aide, Policies, and Growth. American Economic Review, 90, 847-868. https://doi.org/10.1257/aer.90.4.847

Chaitip, P., Chokethaworn, K., Chaiboonsri, C., \& Khounkhalax, M. (2015). Money Supply Influencing on Economic Growth-wide Phenomena of AEC 
Open Region. Procedia Economics and Finance, 24(July), 108-115.

Chipote, P., \& Palesa, M. (2014). Impact of monetary policy on economic growth: A case study Of South Africa. Mediterranean Journal of Social Sciences, 5(15), 76-84. https://doi.org/10.36941/mjss

Chude, N. P., \& Chude, D. I. (2016). Impact of money supply on economic growth in Nigeria. International Journal of Banking and Finance Research, 2(1), 46-53.

Denbel, F. S., Ayen, Y. W., \& Regasa, T. A. (2016). The Relationship between Inflation and Economic Growth in Ethiopia: Co integration and Causality Analysis. International Journal of Scientific and Research Publications, 6(1), 556-565.

Dlamini, D. Armstrong, T. N. (2001). A cointegration analysis of the determinants of inflation in Swaziland. In Central Bank of Swaziland Working Paper.

Evans Ovamba, K. (2014). Relationship between Inflation and Money Supply in Kenya. Journal of Social Economics, 2(2), 63-83.

Fanta, F. (2013). Financial Deregulation, Economic Uncertainty and the Stability of Money Demand in Australia. Economic Papers, 496-511. https://doi.org/https://doi.org/10.1111/1759-3441.12058

Gatawa, N. M., Abdulgafar, A., \& Olarinde, M. O. (2017). Impact of Money Supply and Inflation on Economic Growth in Nigeria (1973-2013). IOSR Journal of Economics and Finance, 8(3), 26-37.

Ghosh, A., \& Philips, S. (1998). Warning: Inflation may be harmful to your growth. International Monetary Fund Staff Papers, 45(4), 672-710.

Gokal, V., \& Hanif, S. (2004). Relationship between Inflation and Economic Growth in Fiji, Working Paper 2004/04, Economics Department Reserve Bank of Fiji Suva.

Guy, D., Paul, M., Miguel, S., \& Sharma, S. (1998). Inflation Targeting as a Framework for Monetary Policy (MF Working Paper 97/35, "Inflation Targeting in Practice").

Hameed, I., \& Ume, A. (2011). of monetary policy on gross domestic product ( GDP ). Interdisciplinary Journal of Contemporary Research in Business, 3.

Hammond, G. (2011). State of the Art of Inflation Targeting. In Handbooks, Centre for Central Banking Studies, Bank of England (4th ed.).

Ihsan, I., \& Anjum, S. (2013). Impact of Money Supply (M2) on GDP of Pakistan. Global Journal of Management and Business Research Finance, 13(6), 2249-4588.

Inam, U. S., \& Ime, B. S. (2017). Monetary policy and economic growth in Nigeria: Evidence from Nigeria. Advances in Social Sciences Research Journal, 4(6), 41-59. https://doi.org/10.14738/assrj.46.2806

Jawaid, S. T., Quadri, F. S., \& Ali, N. (2011). Monetary-fiscal-trade policy and economic growth Pakistan: Time series empirical investigation. International Journal of Economics and Financial Issues, 1(3), 133-138.

Kamaan, C. K. (2014). The effect of monetary policy on economic growth in 
Kenya. International Journal of Business and Commerce, 3(8), 11-24.

Kaplan, F. (2017). The Relationship Between Money Supply, Interest Rate and Inflation Rate : an Endogeneity-Exogeneity Approach. 13(1), 30-38.

Kausar, R., Bhatti, M., \& Gull, S. (2020). An Effect of Money Supply on Economic Growth: Evidence from Pakistan.

Kizito, U. (2013). The Link between Money Market and Economic Growth in

Nigeria: Vector Error Correction Model Approach. International Journal of Social, Behavioral, Educational, Economic, Business and Industrial Engineering, 7(12), 3076-3084.

Krogh, D. C. (1967). Growth and Inflation. South African Journal of Economics, 35(4), 294-311. https://doi.org/10.1111/j.18136982.1967.tb01945.x

Kurniasih, E. P. (2019). The Long-Run and Short-Run Impacts of Investment, Export, Money Supply, and Inflation on Economic Growth In Indonesia. Journal of Economics, Business \& Accountancy Ventura, 22(1).

Kwofie, C., \& Ansah, R. K. (2018). A Study of the Effect of Inflation and Exchange Rate on Stock Market Returns in Ghana. International Journal of Mathematics and Mathematical Sciences. https://doi.org/10.1155/2018/7016792

Levine, R. (1997). Financial development and growth: Views and agenda. Journal of Economic Literature, 35, 688-726.

Liang, Q., \& Teng, J. Z. (2006). Financial development and economic growth: Evidence from China. China Economic Review, 17(4), 395-411. https://doi.org/10.1016/j.chieco.2005.09.003

Maitra, B. (2011). Anticipated money, unanticipated money and output variations in Singapore. Journal of Quantitative Economics, 9(1), 118-133.

Menegaki, A. N. (2019). The ARDL method in the energy-growth nexus field; best implementation strategies. Economies, 7(4), 1-16. https://doi.org/10.3390/economies7040105

Mohamed Aslam, A. L. (2016). Impact of money supply on Sri Lankan economy: An econometric analysis. International Letters of Social and Humanistic Sciences, 67, 11-17. https://doi.org/10.18052/www.scipress.com/ilshs.67.11

Mohammed Ershad, H., \& Mahfuzul, H. (2017). Empirical analysis of the relationship between Money Supply and Per Capita GDP growth rate in Bangladesh. Journal of Advances in Economics and Finance, 2(1). https://doi.org/10.22606/jaef.2017.21005

Moosa, S. (1982). Money, Inflation, and the Monetarist explanation: Evidence from the postwar U.S. Experience. Eastern Economic Journal, 8(2), 101-119.

Murthy, V. N. R., \& Okunade, A. A. (2016). Determinants of U.S. health expenditure: Evidence from autoregressive distributed lag (ARDL) approach to cointegration. Economic Modelling, 67-73. https://ideas.repec.org/a/eee/ecmode/v59y2016icp67-73.html

Njimanted, F. G., Akume, D., \& Mukete, E. M. (2016). The impact of key 
monetary variables on the economic growth of the CEMAC zone. Expert Journal of Economics, 4(2), 54-60.

Nouri, M., \& Samimi, A. J. (2011). The impact of monetary policy on economic growth in Iran. Middle-East Journal of Scientific Research, 9(6), 740-743.

Odedokun, M. O. (1996). Alternative economic approaches for analysing the role of the financial sector in economic growth. Time series evidence from LDC's. Journal of Development Economics, 50(1), 119-146.

Ogunmuyiwa, M. S., \& Ekone, A. F. (2010). Money Supply - Economic Growth Nexus in Nigeria. Journal of Social Sciences, 22(3), 199-204. https://doi.org/10.1080/09718923.2010.11892802

Onyeiwu, C. (2012). Monetary policy and economic growth of Nigeria. Journal of Economics And Sustainable Development, 3(7), 62-71.

Patrick Kanayo, A., \& Ifeoma, A. (2015). Inflation and Growth in Developing Countries: The Nigerian Experience. IOSR Journal of Business and ManagementVer. II, 17(2), 2319-7668. https://doi.org/10.9790/487X172294109

Pesaran, M. H., Shin, Y., \& Smith, R. P. (1999). Pooled mean group estimation of dynamic heterogeneous panels. Journal of the American Statistical Association, 94(446), 621-634.

Qayyum, A. (2006). Money, Inflation, and Growth in Pakistan. The Pakistan Development Review, 45(2), 203-212.

Ross, S. (2020). How does monetary policy influence inflation? https://www.investopedia.com/ask/answers/122214/how-does-monetarypolicy-influence-inflation.asp

Shuaibu, M. A. B., \& Isa, M. (2011). Money supply, inflation and economic growth in Nigeria. Asian-African Journal of Economics and Econometrics, 11(1), 221-237. https://doi.org/10.1504/ajesd.2019.103561

Suleman, D., Wasti, S. K. A., Lal, I., \& Hussain, A. (2009). An empirical investigation between money supply government expenditure, output \& prices: The pakistan evidence. European Journal of Economics, Finance and Administrative Sciences, 17(17), 60-68.

Temple, J. (2000). Inflation and growth: Stories short and tall. Journal of Economic Surveys, 14, 395-426.

The World Bank Group. (1993). The East Asian Miracle.

Tinbergen, N. (1959). Behavior, systematics,and natural selection. https://doi.org/https://doi.org/10.1111/j.1474-919X.1959.tb02388.x

Twinoburyo, E. N., \& Odhiambo, N. M. (2017). Monetary policy and economic growth: A review Of International Literature. Journal of Central Banking Theory and Practice, 2, 123-137.

Vredin, A. (2015). Inflation Targeting and Financial Stability: Providing Policymakers with Relevant Information. BIS Working Paper, 503.

Wellington Garikai, B. (2015). Is Increased Money Supply a Solution to Boost Zimbabwe Economic Growth Path? SSRN Electronic Journal. https://doi.org/10.2139/ssrn.2696669 
IMPACT OF INFLATION TARGETING POLICY FRAMEWORK OF COUNTRIES BETWEEN THE PERIOD OF 2009-

Zapodeanu, D., \& Cociuba, M. I. (2010). Linking money supply with the Gross Domestic Product in Romania. Annales Universitatis Apulensis Series Oeconomica, 1(12), 501-507. 